\title{
MicROSTRUCTURE AND PROPERTIES OF SINTERED METAL MATRIX COMPOSITES REINFORCED WITH SIC PARTICLES
}

MIKROSTRUKTURA I WŁAŚCIWOŚCI SPIEKANYCH KOMPOZYTÓW

O OSNOWIE METALOWEJ UMACNIANYCH CZĄSTKAMI SIC

\begin{abstract}
Based on the prealloyed and diffusion bonded powders (Distaloy SA and Distaloy SE) different metal matrix composites reinforced with $\mathrm{SiC}$ particles were produced by the conventional powder metallurgy technology and the effect of varied amounts of $\mathrm{SiC}$ particles on microstructure evaluation and selected properties were investigated. It was stated that the mass fraction of $\mathrm{SiC}$ has a great effect on the density, porosity, shrinkage, hardness and wear resistance of studied composites. In the case of both Distaloy SA and Distaloy SE matrix materials, the optimum $\mathrm{SiC}$ content is $4 \mathrm{wt}$ \% due to the highest wear resistance and hardness of sintered composite.
\end{abstract}

Keywords: metal matrix composites, $\mathrm{SiC}$ particles, Distaloy SA, Distaloy SE, sintering, density, hardness, wear resistance, microstructure

\section{Streszczenie}

Konwencjonalną technologią metalurgii proszków otrzymano z proszków stopowanych i wyżarzanych dyfuzyjnie kompozyty o osnowie metalowej umacniane cząstkami SiC. Dokonano oceny wplywu udzialu cząstek SiC na ich mikrostrukturę i wybrane właściwości. Udział masowy cząstek SiC wywiera znaczny wpływ na gęstość, skurcz, twardość, odporność na zużycie ścierne badanych kompozytów. W spiekanych kompozytach o osnowie Distaloy SA, jak i Distaloy SE optymalna zawartość SiC wynosi 4 \% wag. ze względu na najwyższą odporność na zużycie ścieranie i twardość.

Słowa kluczowe: kompozyty o osnowie metalowej, cząstki SiC, Distaloy SA, Distaloy SE, spiekanie, gęstość, twardość, odporność na zużycie ścierne, mikrostruktura 


\section{Introduction}

Ceramic particle-reinforced metal matrix composites are an attractive group of structural materials. They have found wide use in various engineering applications, especially for aerospace, automotive, wear and cutting applications [1-9]. This is due to good mechanical properties as well as the combination of special properties with ease of fabrication $[1,3,7,10]$. These industrially important composites exhibit properties which are better in comparison to metals [11]. The most interesting of these are: higher ratio of strength-to-density as well as stiffness-to-density, greater wear resistance and fatigue resistance and better elevated temperature properties $[1,6,8,12]$.

It is worth mentioning that particulate reinforcement has some important advantages in comparison to the other types of reinforcements. Namely the production procedures are simpler and relatively cheaper, the cost of reinforcements is comparatively low, and the properties for the composite are isotropic. And finally, there is good compatibility with most practised manufacturing processes like welding, machining, deformation processing etc. [3, $9,13,14]$. Furthermore, ceramic particles introduced into a metal matrix can greatly enhance the mechanical and tribological properties as well as the anti-corrosion behaviour of such composites $[15,16]$. The most common types of particulate reinforcements are oxides $\left(\mathrm{Al}_{2} \mathrm{O}_{3}\right)$, carbides $(\mathrm{SiC}, \mathrm{TiC}, \mathrm{WC})$ and borides $\left(\mathrm{TiB}_{2}\right)[1,5,10,12,16,17]$. Particle-reinforced MMCs typically contain less than $25 \mathrm{vol}$. \% ceramic reinforcement. The typical dimensions of the most frequently used ceramic particles are within the range between 1 and $100 \mu \mathrm{m}$.

Particle-reinforced MMCs can be produced by both solid state (powder metallurgy technology) $[1,2,4,5,10,11,14,15,17-21]$ and liquid phase techniques (stir casting) [3, $8,12,13,16]$. It should be pointed out that powder metallurgy technology ensures some advantages, namely: lower energy consumption, higher raw material savings, near net-shape or net-shape parts fabrication, part dimensional accuracy, lower cost, simpler equipment for processing and shorter processing times and of course higher composition uniform distribution and a wide range of composition selection for the metal matrix, which is important in the case of production of MMCs [1, 17-20].

Based on a review of the literature, it can be stated that most papers relate to the lightweight metal matrix composites $[4-6,8-13,16]$. It can be noted that aluminium and aluminium alloys are the most popular matrix for particle-reinforcement MMCs. They are very attractive materials due to their low density, their capability to be strengthened by precipitation, good corrosion resistance, high thermal and electrical conductivity, and high damping capacity [8, 11-13]. For these reasons, aluminium and aluminium alloy matrix composites have been extensively investigated in terms of preparation methods as well as parameters affecting the mechanical and tribological properties, and corrosion behaviour as well as microstructure evolution $[4-8,10-12,16]$. Generally, researchers have focused on the influence of the chemical nature of ceramic reinforcements and the chemical composition of the matrix on the microstructure as well as the properties of these composites.

Nevertheless, it should be emphasized that there is a growing interest in iron-based matrix composites. In these MMCs, iron [17-19], low-alloyed steels [1,2, 14], tool steels as well as 
stainless steels $[7,15,21-23]$ are used as the matrix material, while particulate reinforcement is usually $\mathrm{Al}_{2} \mathrm{O}_{3}, \mathrm{TiC}, \mathrm{TiB}_{2}, \mathrm{SiC}, \mathrm{WC}$ or TiN. For example, iron and steel matrix composites reinforced with $\mathrm{TiC}$ or $\mathrm{TiB}_{2}$ ceramic particulates have recently received considerable attention because of good hardness and wear resistance and high values of toughness [7]. Furthermore these materials are easy to fabricate and costs are not high.

Analysis of the literature [17-19] leads to the conclusion that the type and particle size of carbide as well as sintering temperature have an influence on the mechanical properties of the sintered Fe-carbide composites. In the case of sintered Fe - (5 wt. \%) SiC composites, the properties such as tensile strength and hardness increased with decreasing carbide particle size (in the range of $20-32 \mu \mathrm{m}$ ) and increasing sintering temperature (in the range from $1100^{\circ} \mathrm{C}$ up to $1200^{\circ} \mathrm{C}$ ) $[18,19]$. Moreover the tensile strengths and hardness of these materials were higher than those of the sintered Fe-WC composites. According to $[17,19]$ the microstructure of sintered $\mathrm{Fe}$ - carbide composites strongly depends on the sintering conditions. It was observed that some $\mathrm{SiC}$ particles contacting with iron particles may decompose during the sintering process, and then silicon and carbon atoms can diffuse into iron particles which results in the formation of a new phase [17-19]. It was found that the sintering temperature to $1000^{\circ} \mathrm{C}$ assured the preservation of $\mathrm{SiC}$ particles, while sintering temperature to $1150^{\circ} \mathrm{C}$ caused the appearance of $\mathrm{Fe}_{3} \mathrm{Si}$, cementite or perlite. It was also reported [17-19] that some iron silicides (for example, $\mathrm{Fe}_{3} \mathrm{Si}, \mathrm{FeSi}$, and $\mathrm{FeSi}_{2}$ ) can be formed during sintering as a consequence of the reaction between iron and $\mathrm{SiC}$. Moreover, the introduction of too much $\mathrm{SiC}$ powder (more than $8 \mathrm{wt}$. \%) caused the formation of liquid during sintering [17]. The aforementioned decomposition of $\mathrm{SiC}$ particles caused the growth of the voids surrounding the $\mathrm{SiC}$ particles as well as a decrease in the $\mathrm{SiC}$ particle size $[18,19]$. While in the case of $\mathrm{Fe}-\mathrm{WC}, \mathrm{Fe}-\mathrm{TiC}$, and $\mathrm{Fe}-\mathrm{VC}$ composites, carbide particles were stable during heating up to $1200^{\circ} \mathrm{C}$. But sintering at a temperature above $1250^{\circ} \mathrm{C}$ caused decomposition of carbide and reaction between iron and carbide $[18,19]$. Therefore, no improvement in the mechanical properties was observed.

There are also some studies on metal matrix composites reinforced with $\mathrm{SiC}$ particles [1-23]. $\mathrm{Al} / \mathrm{Al}$ alloy - $\mathrm{SiC}[1,3-6,8-13,16], \mathrm{Fe}-\mathrm{SiC}[17-19]$ as well as steel $-\mathrm{SiC}[1$, $2,7,14,15,20-23]$ composites should be primarily listed. It is known that silicon carbide possesses high hardness and good wear resistance, high strength, good thermal characteristics and also resistance to oxidation at high temperatures and a very attractive cost $[1,8,15]$.

For instance, papers $[17,20]$ are related to sintered $\mathrm{Fe}-\mathrm{SiC}$ and $316 \mathrm{~L}$ steel $-\mathrm{SiC}$ composites. In the case of these studies, the content of $\mathrm{SiC}$ varied in the range of $0 \%$ up to $10 \%$. The addition of silicon carbide particles decreased the sintered density of $\mathrm{Fe}-\mathrm{SiC}$ and also 316L - SiC composites. The mechanical properties (UTS, yield strength, elongation, hardness) of the sintered $316 \mathrm{~L}-\mathrm{SiC}$ composites were higher than those of sintered $316 \mathrm{~L}$ steel. Furthermore, the mechanical properties increased with increasing $\mathrm{SiC}$ content [20]. The sintered $\mathrm{Fe}-\mathrm{SiC}$ composites exhibited an increase in UTS, yield strength, and hardness similar to sintered $316 \mathrm{~L}-\mathrm{SiC}$ composites [17].

Due to their properties, the low and medium alloyed steels including Distaloy and also Ancorsteel are widely used in the production of sintered components such as complex, precise, 
high strength machine parts [14, 24-27]. Distaloy is a prealloyed and diffusion bonded powder. This means that the alloying elements i.e. copper, nickel and molybdenum are bonded in particulate form to the basic iron particles. This powder production process, as well as balanced nickel and copper contents, provides the minimum segregation and also contribute to dimensional stability [24]. Distaloy is today widely used in applications demanding high strength and wear resistance. It turns out that low and medium alloyed steels are also good candidates for matrix of MMCs (especially with wear properties) $[14,25,26]$. But thus far there have only been very few papers relating to these particulate-reinforced MMCs $[1,2,14]$.

The microstructure and mechanical properties of sintered Distaloy DC - SiC composites were studied [2]. It was stated that the increase in $\mathrm{SiC}_{\mathrm{p}}$ content (from $0.5 \mathrm{wt}$. \% to 1 wt. \%) decreased the density of sintered Distaloy DC - SiC composites but improved their hardness and wear resistance.

Articles $[1,14]$ deal with Distaloy SA and Distaloy AE MMCs reinforced with SiC particles in an amount of $20 \%$. It was stated that these composites exhibited higher hardness and wear resistance, as well as mechanical properties in comparison with sintered Distaloy steels.

In this study different Distaloy matrix composites reinforced with $\mathrm{SiC}$ particles were produced using the conventional powder metallurgy technology. They were prepared from prealloyed and diffusion bonded Distaloy SA and Distaloy SE powders mixed with silicon carbide in the amount of 2 and $4 \mathrm{wt}$. \%. The primary aim of this study was to determine the effect of the chemical composition on microstructure evaluation and selected properties of sintered Distaloy - SiC composites.

\section{Materials for research}

In the present studies, prealloyed and diffusion bonded powders of Distaloy SA and Distaloy SE (manufactured by Höganäs) were used. The chemical composition of these powders is shown in Table 1. Silicon carbide (product of ALDRICH Chemistry, purity of $99.8 \%)$ was used as particulate reinforcement.

Table 1. Chemical composition of Distaloy SA and Distaloy SE powders (wt.\%)

\begin{tabular}{|l|l|l|l|l|}
\cline { 2 - 5 } \multicolumn{1}{c|}{} & Ni & Cu & Mo & Fe \\
\hline Distaloy SA & 1.75 & 1.50 & 0.50 & Bal. \\
\hline Distaloy SE & 4.00 & 1.50 & 0.50 & Bal. \\
\hline
\end{tabular}

The following powder mixtures were prepared:

- Distaloy SA - 2 wt.\% SiC,

- Distaloy SA - 4 wt.\% SiC,

- Distaloy SE - 2 wt.\% SiC,

- Distaloy SE - 4 wt.\% SiC.

In order to compare the results, pure Distaloy SA and Distaloy SE powders were also used in these studies. 


\section{Experimental procedure}

The abovementioned powder mixtures were prepared by mixing in a Turbula ${ }^{\bowtie}$ mixer for 5 hours. Then different compositions of mixed Distaloy - SiC powders and also Distaloy powders were uniaxially pressed in a rigid matrix at $600 \mathrm{MPa}$ into cylindrical samples of size $₫ 20 \times 5$ [mm]. The sintering process was carried out in a Nabertherm furnace. All green compacts were sintered in a pure $(99.9992 \%)$ and dry (dew point below $-60^{\circ} \mathrm{C}$ ) hydrogen atmosphere. The flow rate of the gas was $100 \mathrm{ml} / \mathrm{min}$. The temperature of isothermal sintering was $1240^{\circ} \mathrm{C}$. The sintering time was 60 minutes. The samples were slowly heated to the isothermal sintering temperature at a rate of $10^{\circ} \mathrm{C} / \mathrm{min}$. The cooling rate from sintering temperature to ambient temperature was also $10^{\circ} \mathrm{C} / \mathrm{min}$.

The density measurements of green compacts were carried out by the geometrical method. The density and porosity of the sintered samples were measured by the water-displacement method (according to the demands of the PN-EN ISO 2738:2001 norm).

Before and after sintering, samples were measured to estimate dimensional changes (PN-EN ISO 4492:2013-07E).

According to PN-EN ISO 4498:2010E the hardness by Vickers method was determined with the computer-aided hardness tester INNOVATEST CV-600.

Wear tests were performed by a ball-on-disc method using a T01-M tester. The various applied loads $(10$ and $20 \mathrm{~N})$ and sliding speeds $(0.12$ and $0.2 \mathrm{~m} / \mathrm{s})$ and a constant sliding distance of $500 \mathrm{~m}$ were used. All wear tests were performed in air and without any lubricant. The wear resistance of the composites was evaluated by means of wear rate.

Metallographic cross-sections were prepared. The microstructural study of the sintered metal matrix composites was conducted with a Nikon Eclipse ME 600P Light Optical Microscope.

\section{Results and discussion}

In Figure 1a) the effect of $\mathrm{SiC}$ content on green and sintered density of Distaloy $\mathrm{SA}$ and Distaloy SA - SiC composites are shown. Figure $1 \mathrm{~b}$ ) presents the same dependence but for Distaloy SE and Distaloy SE - SiC composites. In these composites, the proportions of the matrix and particulate reinforcement are expressed as the weight fraction because it is appropriate to fabrication. However, the weight fraction was converted to volume fraction because it is generally used in property calculations. The rule of mixture is commonly known because it helps in approximating the property values such as the density of composites. Figures 1a) and $1 \mathrm{~b}$ ) also show the values of theoretical sintered density in comparison with the measured density values of the studied Distaloy SA-SiC and Distaloy SE-SiC composites with different weight percentage of $\mathrm{SiC}$.

It can be observed that Distaloy SA has higher green and sintered density in comparison to Distaloy SE, but also Distaloy SA matrix composites reinforced with SiC particles exhibit higher values of these densities relative to Distaloy SE-SiC composites. 
It can be concluded that the presence of $\mathrm{SiC}$ particulate reinforcement caused a reduction in density (as compared to matrix materials) after pressing as well as the sintering process. By adding $\mathrm{SiC}$ to Distaloy up to $4 \mathrm{wt}$. \% green and sintered density decrease. The decrease in density may be attributed to the low density of the $\mathrm{SiC}$ particles. An addition of $\mathrm{SiC}$ particles impedes material densification during sintering and lower relative densities were obtained for sintered Distaloy SA - SiC and Distaloy SE - SiC composites. The effect of the increased number of $\mathrm{SiC}$ particles on the deterioration of sinterability was also found in the case of sintered Distaloy DC - SiC composites [2].

In the case of both Distaloy SA - SiC and Distaloy SE - SiC composites, the values of theoretical and experimental sintered density are different from each other, but the trend of density change is the same: the higher the $\mathrm{SiC}$ content, the lower the sintered density. It can be assumed that the $\mathrm{SiC}$ particles inhibit the transport mechanisms leading to densification of the matrix material during sintering.

a)

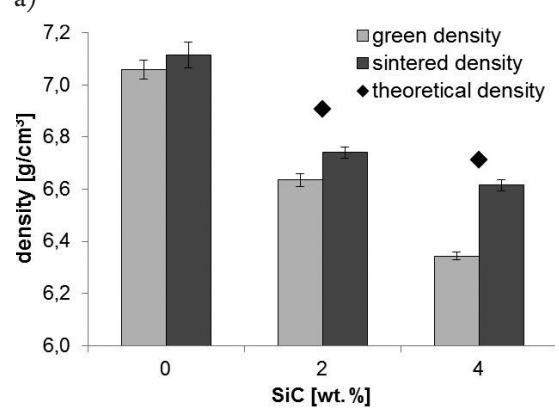

b)

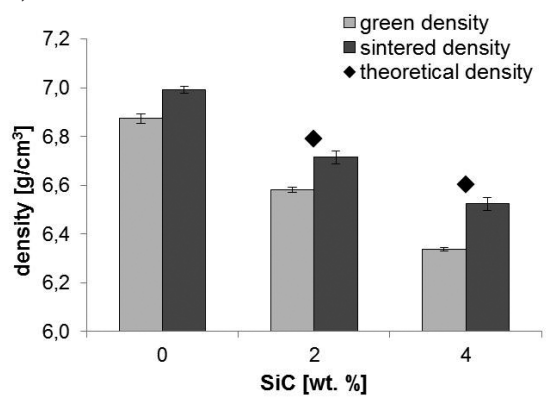

Fig. 1. Green density, theoretical and experimental sintered density:

a) Distaloy SA-SiC composites, b) Distaloy SE-SiC composites

As can be seen in Figures 2a) and 2b), Distaloy-SiC composites exhibit slightly higher open and closed porosity in comparison to sintered Distaloy and furthermore increase of $\mathrm{SiC}$ content up to $4 \mathrm{wt}$. \% decreases values of porosity.

a)

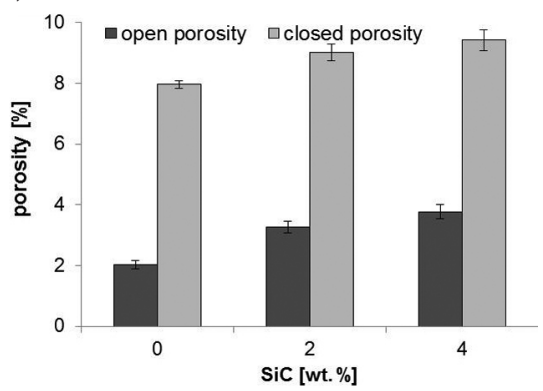

b)

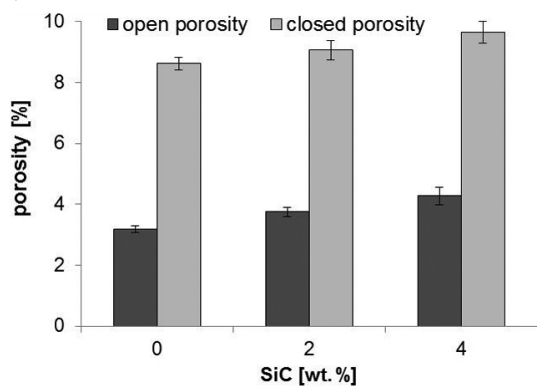

Fig. 2. Open and closed porosity:

a) Distaloy $\mathrm{SA}-\mathrm{SiC}$ composites, b) Distaloy SE-SiC composites 
In order to designate the dimensional change, measurement of samples heights was carried out before and after the sintering process. Figure 3 presents the results obtained. It can be observed that the samples of Distaloy as well as the composites undergo shrinkage during sintering. Distaloy SA shows a slightly higher shrinkage and better densification compared to Distaloy SE. In the case of the composites, increasing $\mathrm{SiC}$ content up to $4 \mathrm{wt}$. \% leads to raising the shrinkage, but this increase in dimensional change does not improve densification. Higher green and sintered density and smaller dimensional shrinkage were observed in Distaloy SA and Distaloy SE.

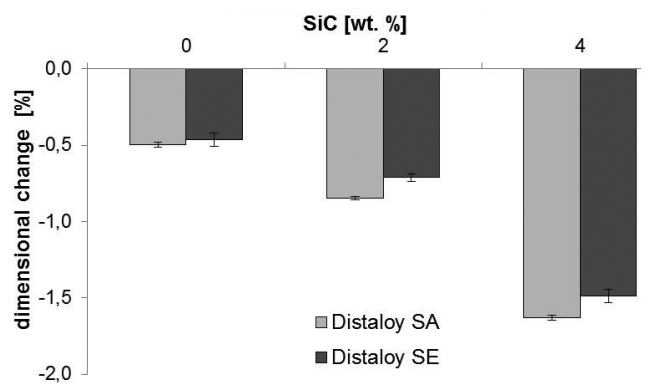

Fig. 3. Dimensional change (designated after sintering) for studied materials

The results of the hardness measurement by the Vickers method of materials studied are presented in Figure 4. It can be observed that Distaloy SA exhibits slightly higher hardness in comparison to Distaloy SE. This is explained by the lower nickel content in the chemical composition of Distaloy SA $(1.75 \% \mathrm{Ni})$ and higher martensite fraction. The presence of particulate reinforcement effects a significant increase in the hardness of the sintered Distaloy $\mathrm{SA}-\mathrm{SiC}$ as well as Distaloy SE - SiC composites. An increasing SiC content up to 4 wt. \% leads to a maximum hardness in the composites studied. The increase in hardness is related to higher hardness of $\mathrm{SiC}$ in comparison to the matrix materials. It can be stated that this is in accordance with the mixtures rule. The introduction of reinforcement having higher hardness to a matrix material with lower hardness leads to higher hardness of composite.

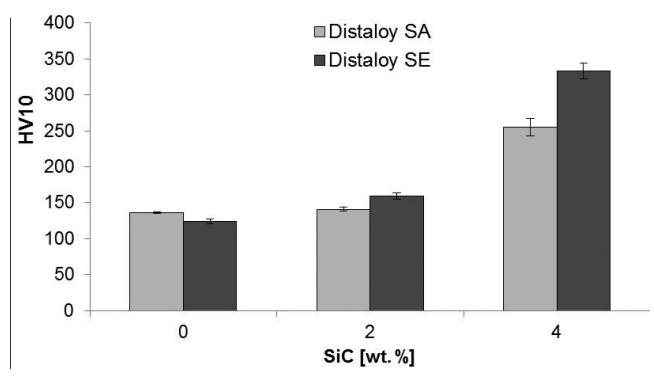

Fig. 4. The effect on $\mathrm{SiC}$ content on hardness of sintered Distaloy SA - SiC and Distaloy SE - SiC composites

Figure 5 shows the variation of the wear rate of the materials investigated. It can be observed that regardless of the applied loads, the wear rate of both Distaloy SA - SiC and 
Distaloy SE - SiC composites is significantly lower than that of their matrix materials and furthermore it decreases with the increase $\mathrm{SiC}$ content. It can be seen that the wear rate of the sintered steels as well as the composites increases with applied load.

This was also observed in the relationship between the hardness and the wear rate of these composites. Namely, the higher the hardness, the lower the wear rate. It can be concluded that Distaloy matrix composites reinforced with $4 \mathrm{wt} . \% \mathrm{SiC}$ reach the highest hardness and wear resistance. These results are consistent with paper [2], namely with the increase in silicon carbide particles (from 0.5 up to $1 \mathrm{wt}$. \%), the micro-hardness and wear rate values of Distaloy DC matrix composites improved.

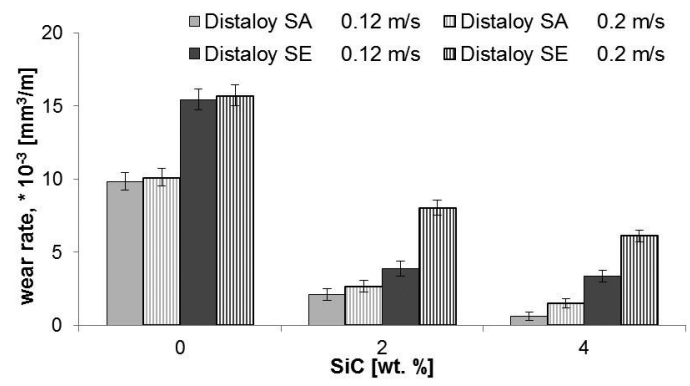

Fig. 5. The effect on $\mathrm{SiC}$ content on wear rate of sintered Distaloy SA - SiC and Distaloy SE - SiC composites

It was confirmed that the microstructure of sintered Distaloy SA and Distaloy SE is a mixture of different phases: ferrite, bainite/pearlite, martensite and Ni-rich austenite [28]. This is due to the chemical heterogeneity of $\mathrm{Cu}, \mathrm{Ni}$ and Mo elements and their low diffusion rate at the sintering temperature. The microstructure observation leads to the following statements. A significant difference in the morphology of porosity between sintered Distaloy and Distaloy matrix composites reinforced with $\mathrm{SiC}$ particles was not found. The shape and size of pores are almost the same. Practically all pores are irregular in shape and partially connected to each other.

The selected microstructures of the composites studied are presented in Figures 6-10.

a)

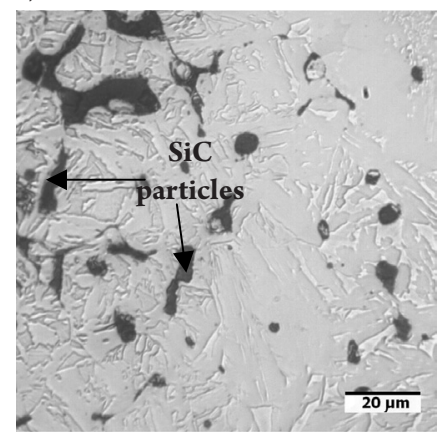

b)

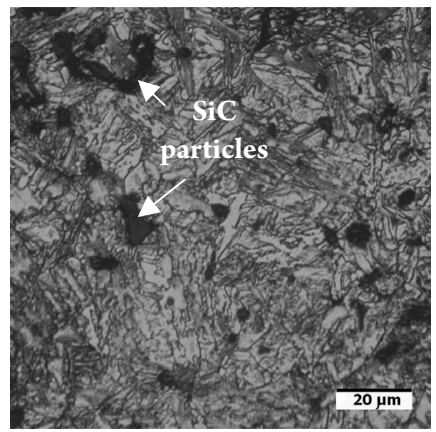

Fig. 6. Microstructure of sintered Distaloy SA - 2 wt.\% SiC composites:

a) unetched, b) Nital etched 
The microstructure studies revealed that the microstructure of investigated materials is heterogeneous. No microstructural gradient between the surface and the centre of the sample was observed. The distribution of $\mathrm{SiC}$ particles is nearly homogeneous. It should be pointed out that the slight agglomeration of fine $\mathrm{SiC}$ particles and formation of porous structure in the areas adjacent to these particles occur in the microstructure of sintered Distaloy SA and Distaloy SE matrix composites. In the case of the composites studied, the microstructure basically consists of a mixture bainite, martensite, ferrite and, of course $\mathrm{SiC}$ particles on the grain boundaries.

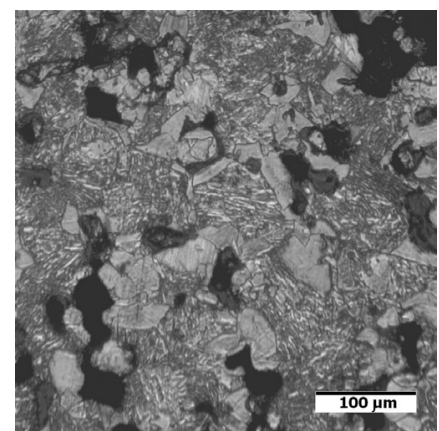

Fig. 7. Microstructure of sintered Distaloy SA - 4 wt.\% SiC composites.

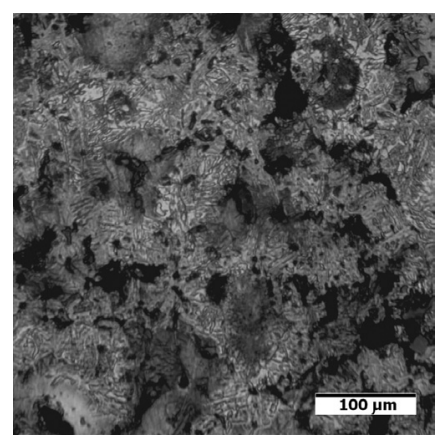

Fig. 9. Microstructure of sintered Distaloy $\mathrm{SE}-2 \mathrm{wt} . \% \mathrm{SiC}$ composites

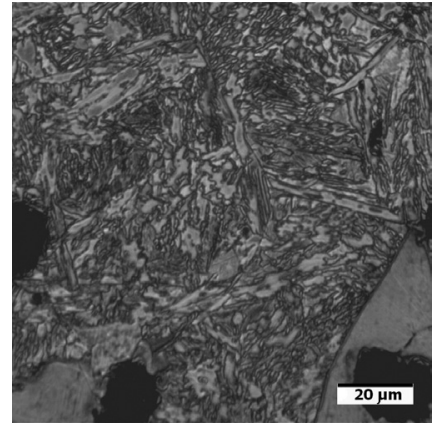

Fig. 8. Microstructure of sintered Distaloy SA - 4 wt.\% SiC composites.

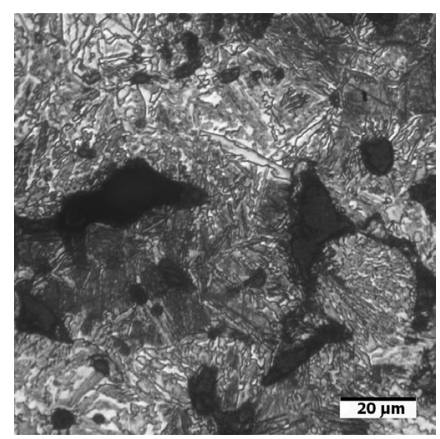

Fig. 10. Microstructure of sintered Distaloy SE - 2 wt.\% SiC composites

\section{Conclusion}

Based on commercially available grades of prealloyed and diffusion bonded powders, metal matrix composites reinforced with $\mathrm{SiC}$ particles were manufactured using the conventional powder metallurgy technology. The experimental results showed that the mass fraction of $\mathrm{SiC}$ has an impact on properties such as the density, porosity, shrinkage, hardness and wear resistance of these composites.

The nickel content in the chemical composition is the basic difference between Distaloy SA and Distaloy SE alloys. In effect, differences in densification after pressing and sintering, as well as the hardness of these materials, can be noted. 
The microstructure studies revealed that the particle distribution is nearly homogeneous. Moreover, the agglomeration of fine $\mathrm{SiC}$ particles was observed, as was the formation of porous structure in the areas adjacent to these particles. The latter have resulted in lower densification and higher porosity of studied composites in comparison to sintered Distaloy. The green density as well as sintered density of Distaloy SA and Distaloy matrix composites decrease by increasing the particulate reinforcement whereas the open and closed porosity increase.

The hardness of these composites increases with the increasing $\mathrm{SiC}$ content. The increase of hardness is related to the presence of hard $\mathrm{SiC}$ particles on the grain boundaries of material matrix.

The results obtained show that the constituents of microstructure and hardness are important parameters affecting the wear behaviour of sintered materials. Materials with microstructure containing basically mixture of martensite, bainite and $\mathrm{SiC}$ particle display a lower wear rate. The higher the hardness of the investigated materials the lower the wear rate, and thus the higher wear resistance.

It was concluded that in the case of both Distaloy SA and Distaloy SE the optimum SiC content is 4 wt. \% due to the highest wear resistance and hardness of the sintered composite.

\section{References}

[1] Badoi I., Dumitru N., Bojin D., Microstructure and Mechanical Behaviour of SiC Particles Reinforced in Aluminium and Iron Matrix Composites, Brasov CEEX Conference, 2008, July 27-29.

[2] Öksüz K., Kumruoğlu L., Tur O., Effect of Sic on the Microstructure and Mechanical Properties of Sintered Distaloy DC Composites, "Procedia Materials Science”, 11/2015, 49-54.

[3] Rawal S., Metal-matrix composites for space applications, "JOM”, 53/2001, 14-17.

[4] Abhik R., Xaviora M., Evaluation of Properties for Al-SiC Reinforced Metal Matrix Composite for Brake Pads, "Procedia Engineering”, 97/2014, 941-950.

[5] Venkatesh B., Harish B., Mechanical properties of metal matrix composites $(\mathrm{Al} / \mathrm{SiC}$ ) particles produced by powder metallurgy, "International Journal of Engineering Research and General Science”, 3(1)/2015, 1277-1284.

[6] Zakaria H.M., Microstructural and corrosion behavior of Al/SiC metal matrix composites, "Ain Shams Engineering Journal", 5(3)/2014, 831-838.

[7] Akhtar F., Ceramic reinforced high modulus steel composites: processing, microstructure and properties, "Canadian Metallurgical Quarterly", 53(3)/2014, 253-263.

[8] Singla M., Dwivedi D., Singh L., Chawla V., Development of Aluminium Based Silicon Carbide Particulate Metal Matrix Composite, "Journal of Minerals \& Materials Characterization \& Engineering”, 8(6)/2009, 455-467.

[9] Kumar G., Rao C., Selvaraj N., Mechanical and Tribological Behavior of Particulate Reinforced Aluminum Metal Matrix Composites - a review, "Journal of Minerals \& Materials Characterization \& Engineering”, 10(1)/2011, 59-91. 
[10] Leszczyńska-Madej B., The effect of sintering temperature on microstructure and properties of $\mathrm{Al}$ - SiC composites, "Archives of Metallurgy and Materials", 58(1)/2013, 43-48.

[11] Nuruzzaman D., Kamaruzaman F., Processing and mechanical properties of aluminiumsilicon carbide metal matrix composites, "Materials Science and Engineering”, 114/2016, 11-17.

[12] Suryanarayanan K., Praveen R., Raghuraman S., Silicon Carbide Reinforced Aluminium Metal Matrix Composites for Aerospace Applications: A Literature Review, "International Journal of Innovative Research in Science, Engineering and Technology”, 2(11)/2013, 6336-6344.

[13] Baisane V. P., Sable Y.S., Dhobe M. M., Sonawane P.M., Recent development and challenges in processing of ceramics reinforced Al matrix composite through stir casting process: A Review, "International Journal of Engineering and Applied Sciences", 2(10)/2015, 11-16.

[14] Badoi I., Tudor A., Development and wear characterization of metal matrix composites in systems prealloyed steel powders reinforcement with $\mathrm{SiC}$ and $\mathrm{Al}_{2} \mathrm{O}_{3}$ particles, Brasov CEEX Conference, 2008, July 27-29.

[15] Carvalho O., Madeira S., Buciumeanu M., Soares D., Silva F.S., Miranda G., Pressure and sintering temperature influence on the interface reaction of $\mathrm{SiC}_{p} / 410 \mathrm{~L}$ stainless steel composites, "Journal of Composite Materials", 50(15)/2016, 2005-2015.

[16] Saravanan C., Subramanian K., Ananda V., Sankara R., Effect of Particulate Reinforced Aluminium Metal Matrix Composite - A Review, "Mechanics and Mechanical Engineering", 19(1)/2015, 23-30.

[17] Yodkaew T., Morakotjinda M., Tosangthum N., Coovattanachai O., Krataitong R., Siriphol P., Vetayanugul B., Chakthin S., Poolthong N., Tongsri R., Sintered $\mathrm{Fe}-\mathrm{Al}_{2} \mathrm{O}_{3}$ and Fe-SiC, "Composites Journal of Metals, Materials and Minerals", 18(1)/2008, 57-61.

[18] Chakthin S., Poolthong N., Thavarungkul N., Tongsri R., Iron-Carbide Composites Prepared by P/M, "Processing Materials for Properties", 2009, 577-584.

[19] Chakthin S., Morakotjinda M., Yodkaew T., Torsangtum N., Krataithong R., Siriphol P., Coovattanachai O., Vetayanugul B., Thavarungkul N., Poolthong N., Tongsri R., Influence of Carbides on Properties of Sintered Fe-Base Composites, "Journal of Metals, Materials and Minerals", 18(2)/2008, 67-70.

[20] Mima S., Yotkaew T., Morakotjinda M., Tosangthum N., Daraphan A., Krataitong R., Coovattanachai O., Vetayanugul B., Tongsri, Carbide-Reinforced 316L Composite, The Fourth Thailand Materials Science and Technology Conference, Pathum Thani, Thailand, 31 March -1 April 2006.

[21] Coovattanachai O., Mima S., Yodkaew T., Krataitong R., Morkotjinda M., Daraphan A., Tosangthum N., Vetayanugul B., Panumas A., Poolthong N., Tongsri R., Effect of admixed ceramic particles on properties of sintered 316L stainless steel, "Advances in Powder Metallurgy and Particulate Materials”, 7/2006, 161-171.

[22] Carvalho O., Soares D., Silva F.S., Optimization of sintering temperature and compaction pressure of stainless steel/SiC composites, $8^{\circ}$ Congresso Nacional de Mecânica Experimental Guimarães, April 21-23, 2010. 
[23] Ertugrul O., Park H.S., Onel K., Willert-Porada M., Structure and properties of SiC and emery powder reinforced PM 316L matrix composites produced by microwave and conventional sintering, "Powder Metallurgy", 58(1)/2015, 41-50.

[24] Lindskog P., The history of Distaloy, "Powder Metallurgy", 56(5)/2013, 351-361.

[25] Karwan-Baczewska J., Processing and properties of Distaloy SA sintered alloys with boron and carbon, "Archives of metallurgy and materials", 60(1)/2015, 41-45.

[26] Zarebski K., Putyra P., Iron powder-based graded products sintered by conventional method and by SPS, "Advanced Powder Technology", 26/2015, 401-408.

[27] Öksüz K.E., Gün T., Şimşir M., The microstructure and wear behaviour of sintered Astaloy 85Mo, "Transactions on Engineering Sciences", 137/2014, 545-552.

[28] Metallography, Höganäs Handbook for Sintered Components, eds. Höganäs AB, 2015. 